\title{
THE ROLE OF WETLANDS IN DECREASING SMALL RIVERS EUTROFICATION IN THE KALININGRAD REGION
}

\author{
Sergey Umansky \\ Marina Kondratenko \\ Maria Shibaeva \\ Kaliningrad State Technical University, Russia
}

\begin{abstract}
The characteristics of possible ways of solving the problem is described as well as the proof of expediency of realization of measures on decrease of the small rivers eutrofication level with the help of self-cleaning abilities of wetlands is given.

As an analog-object for research the river Gurievka (the right inflow of the river Pregel). The water resources of this river are used for hydropower and water-supply fish-breeding farm.

On basis of hydrochemical analysis and usage of bioindication method for saprobity estimation the analysis of state of water ecosystem in carried out for upper, average and undercurrent of the river Gurievka.
\end{abstract}

The waters of the river Gurievka refer to a category "moderately - contaminated".

The first results on wetland cleaning capacity research are described. This wetland is located in the middle part of the river and presented by marshy part of the channel with extention of $120 \mathrm{~m}$.

Typha latifolia L. dominates in aquatic plants community's structure.

The decrease of water contamination level is noted with passing of water through wetland $\left(\mathrm{COD}_{5}\right.$ at the input - 4,1 $\mathrm{мгO}_{2} / л$, at the output - 2,2 $\left.\mathrm{мгO}_{2} / л\right)$.

By results of study of ecological state of the river it is offered to conduct operations on reconstruction of the coastal zone and creation of artificial wetlands on plots subjected to the greatest anthropogenic influence.

\section{KEYWORDS}

Eutrofication; Wetlands; Small rivers; Biotical index; Hydrochemical analysis; Aquatic plants; Biogenic matters. 


\section{INTRODUCTION}

Eutrofication of freshwater pools of the Kaliningrad Region is one of severe ecological problems. The excessive receipt of biogenic matters with a river drain boosts eutrofication of seawater, that hinders the stable progressing of the Baltic Sea. The main rivers of the region (the Neman \& the Pregolia) and their inflows accept a plenty of pollutants. It is possible to indirectly judge about state of the day waters quality on the basis of indices of the annual azote and phosphorus offset with sewage for a period of $1996-2001[1,2]$ and efficiency of the sewage purification (Table $1 \& 2$ ).

Table 1. Dynamics of downthrow of biogenic matters (tons) with sewages

\begin{tabular}{|l|l|l|l|l|l|l|}
\hline Biogenic matters & 1996 & 1997 & 1998 & 1999 & 2000 & 2001 \\
\hline Azote common & $\begin{array}{l}2005.7 \\
4\end{array}$ & 2839.36 & 2206.93 & 2401.84 & 2484.82 & 1854.64 \\
\hline Phosphates & 285.79 & 236.98 & 301.61 & 265.07 & 218.13 & 181.05 \\
\hline
\end{tabular}

The data of Table 1 demonstrate, that for the last six years the cardinal dynamics in the decrease of downthrow of biogenic matters is not observed. Only in 2001 some reduction of receipt of azote and phosphorus is noted. These data are confirmed by Table 2, which presents the amount of sewage (including unrefined), removed from the territory of the Kaliningrad Region to the water objects.

Table 2. Amount of sewage (mln. $\left.\mathrm{m}^{3} / y e a r\right)$ in the Kaliningrad Region

\begin{tabular}{|l|l|l|l|}
\hline Parameters & Years & 2000 & 2001 \\
\cline { 2 - 4 } & 1999 & 179.5 & 175.8 \\
\hline Sewage disposal, total & 161.9 & 152.3 & 149.8 \\
\hline Including contaminated drains & 134.1 & 85 & 85 \\
\hline $\begin{array}{l}\text { Downthrow of the contaminated } \\
\text { drains in \% of the total amount of } \\
\text { sewage }\end{array}$ & 83 & & \\
\hline
\end{tabular}

The data on the annual amount of biogenic matters in the main rivers of the Kaliningrad Region, in intemal and territorial seawaters, are presented in Table 3. 
KALMAR ECO-TECH'03

Bioremediation and Leachate Treatment

KALMAR, SWEDEN, November 25-27, 2003

The table 3. Annual receipt of azote and phosphorus with sewages in water objects of the Kaliningrad Region [1]

\begin{tabular}{|l|l|l|}
\hline Recipients of sewages & Azote common, $\mathrm{t}$ & $\begin{array}{l}\text { Phosphorus } \\
\text { common, } \mathrm{t}\end{array}$ \\
\hline The Pregolia & 181 & 45 \\
\hline The Neman & 234 & 12 \\
\hline Territorial and seawaters & 2070 & 161 \\
\hline Total & 2485 & 218 \\
\hline
\end{tabular}

Thus, only through the organized sewage disposals in pools of Kaliningrad Region approximately 2,500 tons of azote and 200 tons of phosphorus common are thrown off annually.

However, these are not the unique sources of biogenic elements receipt. An essential constituting part is their diffuse inflow arriving at a hydrological net from the urban territories, agricultural grounds, and woods. The share of agricultural grounds in our region constitutes more than $52 \%$ of all the territory. Such a feature allows speaking about a substantial contribution of diffuse sources of biogenic matters receipt in the water objects of the Baltic Sea. Besides it is necessary to take into account the receipt of azote and phosphorus from the bottom sediments of pools [3].

The Kaliningrad Region is characterized as an exuberant one in the resources of fresh water as of $25,600 \mathrm{~m} 3 /$ year of water per capita [1], however the stoppages in submission of potable water in a summer period have been observed recently. Eutrofication of surface sources of a water supply should count as one of the reasons for this phenomenon. Eutrofication also negatively influences fishery and recreational usage of water objects of the region.

The purpose of the present work is in presenting original theses of the policy on the decrease of the small rivers eutrofication, the ecosystems of which are the most responsive to anthropogenous effects. However, the small rivers in the Kaliningrad Region practically are not studied from this point of view. Besides, here there are more than 4,500 small rivers of a common length of more than $10,700 \mathrm{~km}$. Anthropogenous loads onto the river net of the region as per indices of the biogenic matters drain vary from 30 to $100 \mathrm{t} /$ year (phosphorus) and from 200 to 1,000 (azotes), concentrations of phosphorus and azote, accordingly $0.18-0.20 \mathrm{mg} / \mathrm{l}$ and $1.7-2.0 \mathrm{mg} / \mathrm{l}[4]$. 


\section{FIELD STUDIES}

The river Guryevka was selected as object of study the right inflow of the river Pregolia. The river Guryevka starts in a marshy wood, to the east of the Lake Divnoe. The common length of the river is of $26.3 \mathrm{~km}$, the floor space of the basin $-116.3 \mathrm{~km}^{2}$ (Fig. 1). Average annual water discharge $-0.96 \mathrm{~m}^{3} / \mathrm{s}$. The water resources of this river are used for hydropower engineering and water-supply of a fish-farm. The water yield of the river Gurievka has a cascade of three river-bed ponds.

The sewage from chicken farm and from territories of three village run into the river.

The program of studies powered up following directions.

1). On the mid-current of the river, since autumn 2002 the seasonal monitoring of the aquatic plants influencing the quality of river waters has been held. The samples of water were taken on the input t $j$ and escape from the overgrowth of aquatic plants (Fig. 2). The quality of water was controlled by the following parameters: dissolved oxygen, $\mathrm{BOD}_{5}$, electrical conductivityt $\mathrm{pH}$, nitrites and phosphates.

2). Study of dynamics of biogenic impurity lengthwise the river. In summer and in the beginning of autumn 2003 there was conducted sampling of bentos organisms and hydrochemical studies of water on stations in upstream, mid-current and undercurrent of the river. The samples were taken at four stations, reflecting the features of the water mode and anthropogenous activity. Their location is exhibited on Fig. 1.

The investigated plot with aquatic plants is in the undercurrent of the river Guryevka. This plot represents a swampy fragment of the channel of the river, with the length of 120 $\mathrm{m}$, running in the outskirts of Guryevsk. Among the aquatic plants dominate broad-leaved cat's-tail (Typha latifolia L.) and sedges (Carex). The reed (Phragmites communis Trin.) is presented to a lesser degree. In the summer period the channel practically completely overgrown with aquatic plants. The fouling influence is made by the spring, running into the Guryevka in top wetland (Fig. 2). 


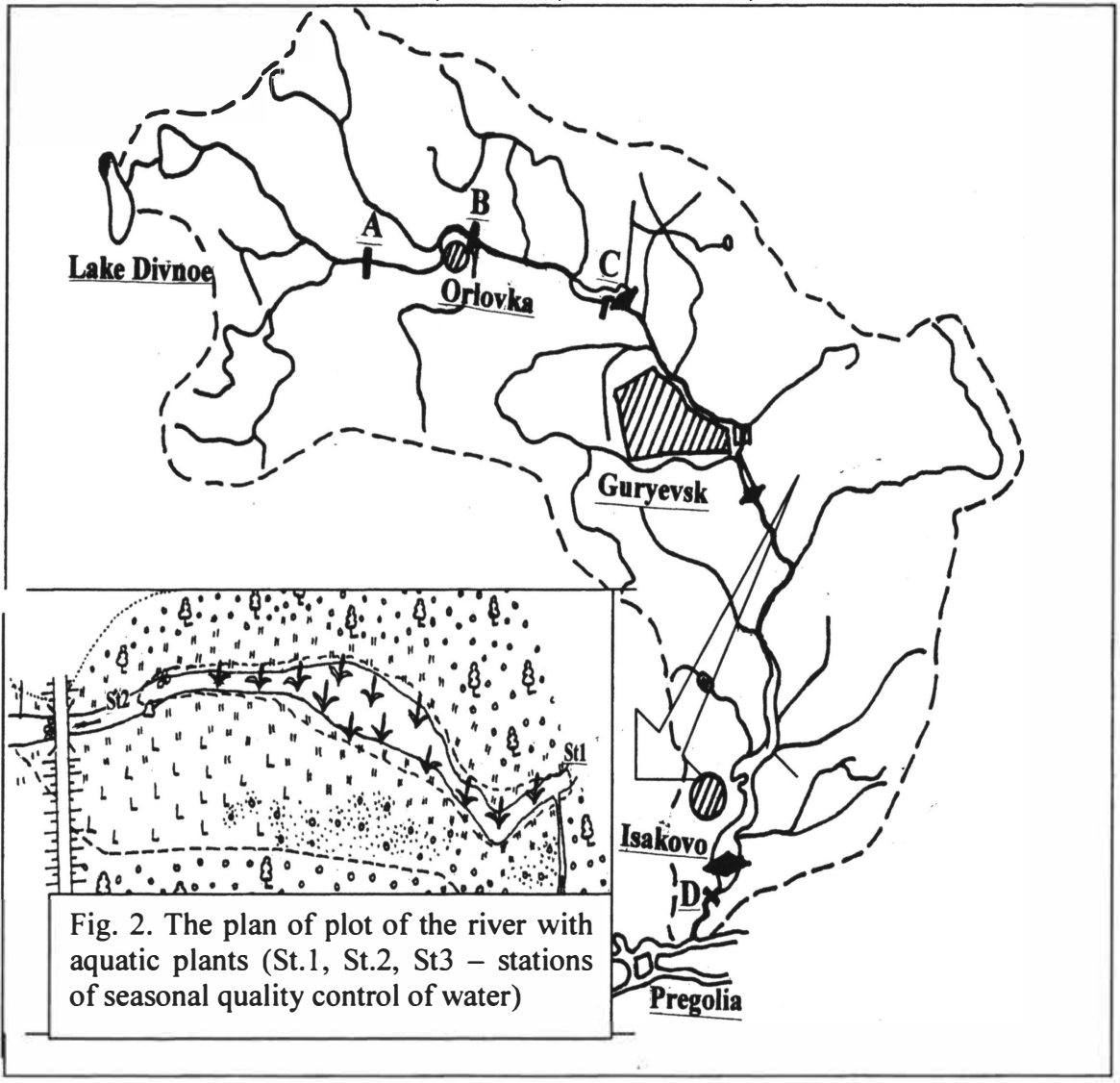

Fig. 1. The schema of Guryevka River's basin ( $A, B, C, D$-stations of quality control of water)

The outcomes of seasonal monitoring are presented in Table 4.

The analysis of the received results leads to the coclusion of the aquatic plants in the period vegetation to improve the quality of the river water. It is seen from the $\mathrm{BOD}_{5}$ parameters, electrical conductivity, phosphorus and azote. The efficiency of water purification in this wetland is a little reduced in the result of fouling influence of the spring. Probably, the efficiency of purification water is also reduced because of the processes of secondary impurity due to the receipt of biogenic matters from decomposed vegetative oddments. The analysis of water purification in communities of aquatic plants can be conducted in an experiment. 
KALMAR ECO-TECH'03

Bioremediation and Leachate Treatment

KALMAR, SWEDEN, November 25-27, 2003

The study outcomes of water impurity dynamics lengthwise the rivers from the source to the estuary are presented in Table 5.

Table 4. Parameters of the river's water quality coming and flowing out the wetland

\begin{tabular}{|c|c|c|c|}
\hline Parameters & $\begin{array}{c}\text { Station } 1 \\
\text { (Above overgrowth } \\
\text { of aquatic plants) }\end{array}$ & $\begin{array}{c}\text { Station } 3 \\
\text { (Water of ta } \\
\text { stream) } \\
\end{array}$ & $\begin{array}{l}\text { Station } 2 \\
\text { (Below of } \\
\text { wetland) }\end{array}$ \\
\hline \multicolumn{4}{|c|}{ Autumn of 2002} \\
\hline $\begin{array}{l}\text { Electrical conductivity, } \\
\text { ms }\end{array}$ & 740 & 832 & 670 \\
\hline $\mathrm{BOD}_{5}, \mathrm{mg} / \mathrm{l}$ & 4.11 & 5.95 & 2.21 \\
\hline Phosphates, mg/l & 0.2 & 1.65 & $\mathbf{0 , 1}$ \\
\hline Nitrites, mg/l & 0.17 & 0.92 & 0.17 \\
\hline Dissolved $\mathrm{O}_{2}, \mathrm{mg} / \mathrm{l}$ & 1.94 & 6.24 & 3.29 \\
\hline \multicolumn{4}{|c|}{ Winter of 2003} \\
\hline $\begin{array}{l}\text { Electrical conductivity, } \\
\text { ms }\end{array}$ & 457 & * & 460 \\
\hline $\mathrm{BOD}_{5}, \mathrm{mg} / \mathrm{l}$ & 3.23 & $*$ & 3.54 \\
\hline Phosphates, mg/ & - & * & - \\
\hline Nitrites, mg/l & - & $*$ & - \\
\hline Dissolved $\mathrm{O}_{2}, \mathrm{mg} / \mathrm{l}$ & 15.03 & $*$ & 15.02 \\
\hline \multicolumn{4}{|c|}{ Spring of 2003} \\
\hline $\begin{array}{l}\text { Electrical conductivity, } \\
\text { ms }\end{array}$ & 560 & 780 & 560 \\
\hline $\mathrm{BOD}_{5}, \mathrm{mg} / \mathrm{l}$ & 4.87 & 8.19 & 3.27 \\
\hline Phosphates, mg/l & 0.16 & 0.13 & 0.13 \\
\hline Nitrites, mg/l & 0.17 & 0.18 & 0.17 \\
\hline Dissolved $\mathrm{O}_{2}, \mathrm{mg} / \mathrm{l}$ & 9.50 & 10.42 & 8.15 \\
\hline \multicolumn{4}{|c|}{ Summer of 2003} \\
\hline $\begin{array}{c}\text { Electrical conductivity, } \\
\text { ms }\end{array}$ & 593 & 764 & 610 \\
\hline $\mathrm{BOD}_{5}, \mathrm{mg} / \mathrm{l}$ & 3.10 & 6.70 & 3.40 \\
\hline Phosphates, mg/l & 0.67 & 1.65 & 0.71 \\
\hline Nitrites, mg/1 & 0.24 & 0.92 & 0.34 \\
\hline Dissolved $\mathrm{O}_{2}, \mathrm{mg} / \mathrm{l}$ & 5.10 & 8.5 & 3.80 \\
\hline
\end{tabular}

*In winter the quality control of water was not conducted because of absence of a drain.

The following landscape features are characteristic for the upstream of the river Guryevka. The source of the river is in a woody marshy terrain. Then approximately after two kilometers the river enters an open territory and flows among agricultural grounds, executing functions of the open drainage header. Its channel is not more than $2 \mathrm{~m}$; the banks abruptly break to the edge of water. Bottom is sandy and oozy. The channel is 
KALMAR ECO-TECH'03

Bioremediation and Leachate Treatment

KALMAR, SWEDEN, November 25-27, 2003

overgrown with aquatic plants in summer, which completely covers the surface of water. Such conditions are characteristic for a plot the boundary of which is formed by point A (Fig. 1).

The anthropogenous load on this section of the river is presented by the basic biogenic drain from agricultural lands. The outcomes of the water analysis demonstrate, that the content of the biogenic matters on this plot of the river is insignificant, though $\mathrm{BOD}_{5}$ exceeds acceptable values.

The Point B controls a plot of the river, which drives through the residential zones of the village Orlovka. It allows watching the nature of the population influencing on the quality of the river water. On this plot the sharp increase of concentration of azotes is noted. Besides, the high enough parameters of $\mathrm{BOD}_{5}$ for upstream of the river were observed which can be possibly explained by the processes of destruction of organic matter from the bottom sediments.

Table 5. Dynamics of water quality lengthwise the river Guryevka (26.09.2003)

\begin{tabular}{|c|c|c|c|c|}
\hline Parameters & $\begin{array}{c}\text { Point A } \\
\text { (upstream) }\end{array}$ & $\begin{array}{c}\text { Point B } \\
\text { (upstream, is } \\
\text { lower than } \\
\text { village } \\
\text { Orlovka) }\end{array}$ & $\begin{array}{c}\text { Point C } \\
\text { (mid- } \\
\text { current, pond } \\
\text { about village } \\
\text { Orlovka) }\end{array}$ & $\begin{array}{c}\text { Point D } \\
\text { (undercurrent) }\end{array}$ \\
\hline Nitrites, mkg/l & 35 & 720 & 45 & 210 \\
\hline Phosphates, mkg/l & 140 & 135 & 60 & 545 \\
\hline Iron common, mkg/1 & 172 & 168 & not & not \\
\hline BOD, $\mathrm{mg} / \mathrm{l}^{\text {Electrical conductivity, }}$ & 6.60 & 6.40 & 5.80 & 1.40 \\
\hline$\mu \mathrm{s}$ & 421 & 427 & 449 & 551 \\
\hline $\begin{array}{c}\text { pH } \\
\text { missolved Oxygenium, }\end{array}$ & 7.1 & 7.0 & 7.5 & 7.3 \\
\hline $\begin{array}{c}\text { Temperature of water, } \\
\text { gr. C }\end{array}$ & 9.6 & 8.50 & 8.30 & 6.00 \\
\hline
\end{tabular}

The Point $\mathrm{C}$ is at the damp of a pond, which is $80 \%$ overgrown with underwater and surface vegetation. In the upper pond, in the zone of shallow waters bur reed dominates in structure of the vegetative communities. Underwater vegetation the primary presented broad-leaved cat's-tail is presented in smaller amount by pondweed and Chara. The abundance of water vegetation allows to consider this pond as a wetland. The outcomes of the hydrochemical analysis confirm this conclusion. The contents of biogenic matters and iron common here are reduced, though $\mathrm{BOD}_{5}$ remains at a previous level.

The Point $\mathrm{D}$ is a closing one, and also controls a plot of the undercurrent, which is characterized by the greatest anthropogenous load, as the river flows through the town Guryevsk. The sewage from chicken farm and unorganized issues of residential sewage 
KALMAR ECO-TECH'03

Bioremediation and Leachate Treatment

KALMAR, SWEDEN, November 25-27, 2003

run into the river. The drain of the river below the town is adjusted by two ponds (Fig. 1). The sewage of the village Isakovo practically without purification is thrown off in the pond Chisty - a shallow, eutrofical pool. The water from this pool is used for the watersupply of a fish-farm. There is a small hydropower plant on the overflow channel from a pond. The operation of its turbines is of a certain importance for the decrease of the eutrofication level. The contents of biogenic matters in the water on this plot is noticeably higher, than that in the previous ones. Primarily, it refers to the concentration of phosphates.

In order to receive the best understanding of the ecological state of the river, the samples of zoobentos were taken and the analysis of water quality using the method of bioportrayal was conducted at the same points. The outcomes and discussion are presented below.

The distribution of species was varied. Amphipodae were met more often, and caddies flies-less often. The dominating group is not expressed. At every station - dominant species were different both in number, and in biomass.

\section{Namber,\%}

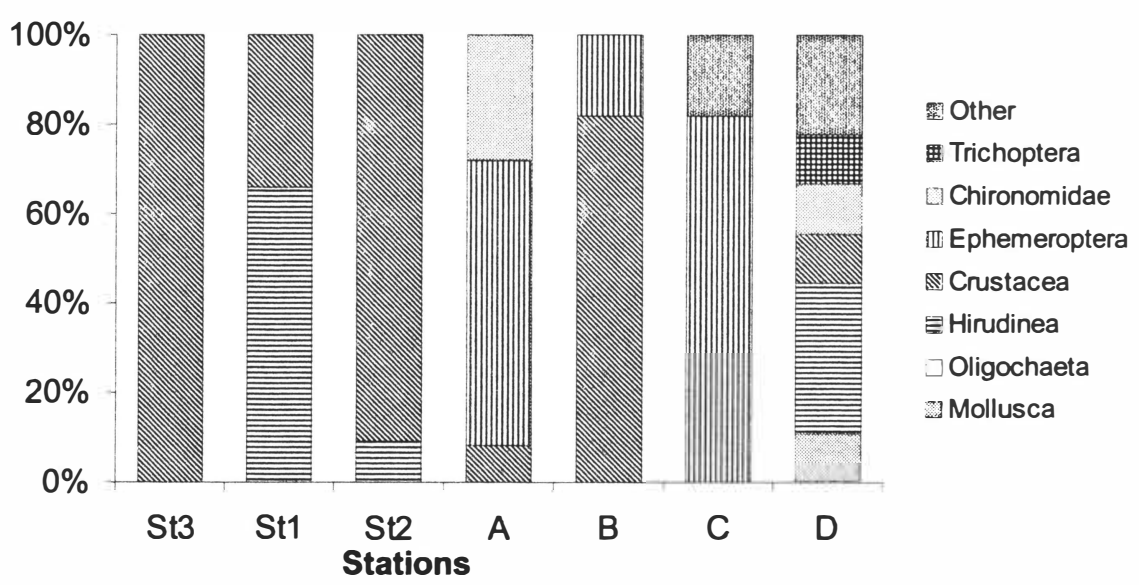

Fig. 3. Number of ground organisms on plots of the upstream, midcurrent and undercurrent of the river Guryevka between basic groups in number and biomass) 


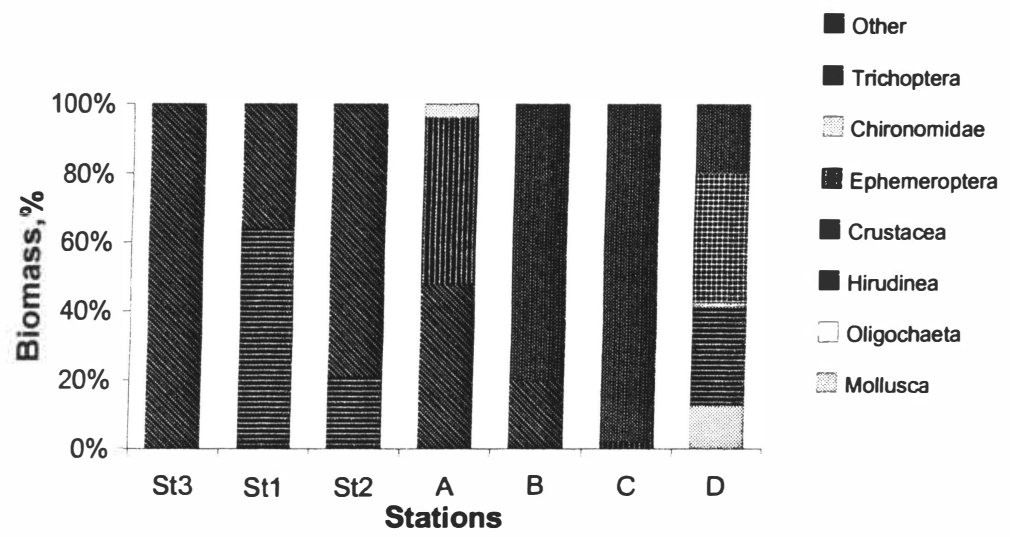

Fig. 4. A biomass of bottom organisms on plots of the upstream, midcurrent and undercurrent of the river Guryevka

This property is characteristic for a category of the small rivers as their hydrological mode is defined by the local factors, thus creating the most diversified conditions for the bottom organisms life.

The flowing places are occupied by reofil's organisms, such as amphipodae, dayflies and caddies flies, and the place with a retarded flow by asellus aquatic's, leeches, sialids, molluscums.

The set of species in the same group can be diversified, depending on the conditions at the station.

Number and biomass of bentos during studies remained considerable, as fenological summer continued in ponds (Tab. 7).

Sharp variations of the number of zoobentos (on the order and more) between stations was not observed. The change amplitude of biomass is also smooth and corresponds to the transitory level of efficiency - from low to average. It is possible to guess, that ecological conditions in the basin of the river are approximately identical. Biotical index one of the parameters of the water quality - specifies it also. The indices are low and also correspond to the moderate and average pollution of water. As per indicator properties of the most frequent species, the water of the river refers to the transitory class, between Classes II and III of water quality, according to the four-class Libman's system [5, 6]. 
KALMAR ECO-TECH '03

Bioremediation and Leachate Treatment

KALMAR, SWEDEN, November 25-27, 2003

Table 7. Number (species $/ \mathrm{m}^{2}$ ) and biomass $\left(\mathrm{g} / \mathrm{m}^{2}\right)$ of basic groups of zoobentos, biotical index (BI) and degree of impurity water of the river Guryevka (September 2003).

\begin{tabular}{|l|c|c|c|c|}
\hline \multirow{2}{*}{$\begin{array}{l}\text { Group of } \\
\text { organisms }\end{array}$} & \multicolumn{4}{|c|}{ The title of stations } \\
\cline { 2 - 5 } & $\begin{array}{c}\text { Point A } \\
\text { (upstream) }\end{array}$ & $\begin{array}{c}\text { The point B } \\
\text { (upstream, is } \\
\text { lower than } \\
\text { village Orlovka) }\end{array}$ & $\begin{array}{c}\text { Point C } \\
\text { (midcurrent, pond } \\
\text { about village } \\
\text { Orlovka) }\end{array}$ & $\begin{array}{c}\text { Point D } \\
\text { (undercurrent) }\end{array}$ \\
\hline Leeches & & & & $14 / 0.464$ \\
\hline Molluscums & & & & $5 / 0.207$ \\
\hline Crustaceous & $63 / 0.540$ & $5 / 0.033$ & & \\
\hline Day-flies & & $41 / 0.033$ & $14 / 0.006$ & $5 / 0.612$ \\
\hline Caddies-flies & & $18 / 0.003$ & & $5 / 0.009$ \\
\hline Chironomidae & & & $5 / 0.306$ & $15 / 0.018$ \\
\hline Dragonfly & & & & $5 / 0.311$ \\
\hline Sialids & $14 / 2.214$ & $64 / 0.069$ & $19 / 0.312$ & $49 / 1.621$ \\
\hline Total & $77 / 2.754$ & 2 & 2 & 2 \\
\hline BI & 3 & Average & Average & Average \\
\hline Pollution & Moderate & & & \\
\hline
\end{tabular}

Note: In numerator - number, in a denominator - biomass of organisms.

\section{CONCLUSION}

- The river is a subject to moderate and average impurity by biogenic matters at all length from the source up to the estuary. The parameters of the elemental composition of water and significance of biotical index testify it.

- Aquatic plants, well developed on open plots of the channel and the dock spaces of ponds, play a key role in maintaining the infringed balance of biogenic matters at all length of the river. Concentrations of biogenic matters in studied points confirm this conclusion. The data on water quality in the undercurrent (point D) are an exception. The increased content of azote and phosphorus was observed here.

- Problems of eutrofication in this small river is a reflection of the general situation in the hydrographical net of the Kaliningrad Region. Therefore, it is necessary to start realization of the policy of eutrofication decrease. It is necessary to initiate the development of the water's quality regulation system with the help of aquatic plants (except for measures on sewage clearing and abatement of pollutants downthrows), as a prime, ecologically flexible and economically expedient measure.

\section{REFERENCES}

[1] Состояние окружающей природной среды в Калининградской области в 2000 году. /Комитет природных ресурсов по Калининградской области. - Калининград, 2001.t- 160tc.

[2] Доклад о состоянии и об охране окружающей природной среды в Калининградской области в 2001 году./ Комитет природных ресурсов по Калининградской области. - Калининград, 2002. - 160 с. 
KALMAR ECO-TECH'03

Bioremediation and Leachate Treatment

KALMAR, SWEDEN, November 25-27, 2003

[3] БЕРНЕТ (2001t): Управление эвтрофикацией в регионе Балтийского моря региональный подход. - Основной отчет по проекту БEPHET. - Odense, Danmark, $200 \mathrm{lt}$, сентябрь.

[4] Географический атлас Калининградской области. /Гл. ред. В.В. Орленок Калининград: Изд-во КГУ, ЦНИТ, $2002-276$ с.

[5] Руководство по методам гидробиологического анализа поверхностных вод и донных отложений. - Л.: Гидрометеоиздат, 1983. - $273 \mathrm{c.}$

[6] Унифицированные методы исследования качества вод. // Методы биологического анализа воды. Часть III. - М.: Издательство СЭВ, 1976 - 186 с. 